\title{
Restoration Strategies in an Area Invaded by Pteridium aquilinum (L.) Kuhn
}

\author{
Thayane Ferreira Carvalho ${ }^{1}$ (D), Israel Marinho Pereira ${ }^{2}$ (D), \\ Soraya Alvarenga Botelho ${ }^{1}$ (D), Miranda Titon² (D), Anderson Cleiton José ${ }^{1}$ \\ ${ }^{1}$ Departamento, Universidade Federal de Lavras - UFLA, Lavras/MG, Brasil \\ ${ }^{2}$ Departamento, Universidade Federal dos Vales do Jequitinhonha e Mucuri - UFVJM, Diamantina/MG, Brasil
}

\begin{abstract}
Pteridium aquilinum is an invasive species that stands out for its aggressiveness, invading pastures, agricultural areas and forests. In order to improve this situation, several techniques have been tested, although not common to tropical climate areas. Thus, the objective of this study was to evaluate the survival of eleven tree species according to their density, planting model, and way of bracken removal, in the restoration of an Atlantic Forest area invaded by the species after a fire. The experiment was installed in a randomized block design, in a $2 \times 3 \times 2$ factorial arrangement (planting $\times$ density $\times$ bracken removal methods). Bracken cover and survival were evaluated nine months after planting. In conclusion, more densified plantations with fast-growing species, together with bracken removal by harrowing, were more effective in establishing the species in bracken-dominated areas.
\end{abstract}

Keywords: biological control, invasive species management, Atlantic Forest. 


\section{INTRODUCTION}

Invasive species greatly impact the invaded sites, because in establishing themselves they develop self-regenerative populations, occupying the space of the native species in order to alter the structure of the ecosystem and its natural ecological processes (Leão et al., 2011; Vilà et al., 2011). In Brazil, there are hundreds of species with invasive potential, such as some types of African grasses and brackens of the genus Pteridium (Matos \& Pivello, 2009). The latter has been a worldwide problem, invading pastures, agricultural areas, and degraded or disturbed forest environments (Pakeman et al., 2002).

Pteridium aquilinum (L.) Kuhn is a species of bracken belonging to the family Dennstaedtiaceae. It is considered an invasive species that infests several types of environments, mainly open places with high incidence of light (Durão et al., 1995). The greatest problem that it causes consists in the dominance of areas in the initial stage of succession because, when forming a dense canopy with a high accumulation of litter, it hinders the arrival of propagules, which in the long run, leads to the impoverishment of the seed bank (Sax et al., 2005). This causes intense damages to the ecosystem, such as the stagnation of successional processes, which in turn leads to a mono-dominant community with almost no diversity (Alday et al., 2013).

In order to revert the biological invasion caused by bracken in disturbed forest ecosystems, several forms of control and restoration techniques have been tested (Roos et al., 2011).

The mechanical control is a method that consists of damaging the leaves and rhizomes by means of heavy machines (Ghorbani et al., 2006), reducing the cover of the bracken slowly. For the efficacy of the mechanical methods, some authors suggest that techniques that have the ecological succession as a principle are applied later (Douterlungne et al., 2013). The method is based on the attempt to inhibit the development of bracken by introducing other vegetation, such as direct seeding, planting of seedlings, among others (Alday et al., 2013).

The planting of tree species has been intensively carried out in recent years in the restoration of degraded areas due to the high adaptive value of the species to the local conditions, allowing, in the short term, protection and enrichment of the soil, shelter and food for the fauna, perpetuation of the water regime and landscape recovery (Rodrigues et al., 2010; Sansevero et al., 2011; Nunes et al., 2015). For this technique to succeed, it is necessary to select the species that will compose the planting in a judicious way, based on the growth rate, adaptation to the habitats to be restored, and functions that they can exert in the restored ecosystem (Reis et al., 2003).

In addition to the correct choice of species, other issues should still be taken into account, such as the density and the model of planting to be used, since these directly influence the optimization of the available resources use, growth rate, shading, planting and maintenance costs (Piña-Rodrigues et al., 1997; Nascimento et al., 2012).

In this context, the objective of the present study is to evaluate the efficiency of control methods and restoration models in an Atlantic Forest area dominated by brackens after a fire.

\section{MATERIAL AND METHODS}

\subsection{Characterization of the study area}

The experiment was carried out in a degraded area under bracken invasion (Pteridium aquilinum) located in the Natural Reserve of Fazenda Fartura (RPPN - Reserva Particular do Patrimônio Natural), in the municipality of Capelinha, Minas Gerais, belonging to the Electric Company Minas Gerais (CEMIG - Companhia Elétrica de Minas Gerais). The RPPN is located between the parallels $15^{\circ} 30^{\prime}$ and $18^{\circ} 30^{\prime} \mathrm{S}$ and the meridians $39^{\circ} 50^{\prime}$ and $43^{\circ} 50^{\prime} \mathrm{O}$, in the northeaster region of Minas Gerais (Minas Gerais, 2009). The area has about three hectares and went through a fire in 2011, propitiating the colonization and establishment of bracken leading to the formation of a dense and homogeneous cover of the species.

The surrounding vegetation is characterized by the occurrence of Semidecidual Seasonal Forest. The climate of the region is classified as humid temperate with dry winter and hot summer (CWa) according to the Köppen classification, with average annual temperature around $21.5^{\circ} \mathrm{C}$ (Baars et al., 1997) and average rainfalls between $200 \mathrm{~mm}$ to $900 \mathrm{~mm}$, distributed irregularly throughout the year (Ferreira \& Silva, 2012). 
Precipitation data of the Capelinha region, collected while carrying out the experiment from March 2015 to December 2015, according to INMET (2016), are presented in Figure 1.

The soils of the area are classified as belonging to the orders Argisols and Latosols, and the suborders of Red-Yellow Argisols and Red and Yellow Latosols (UFV, 2010). The relief of the region has varied forms ranging from lower parts such as valley bottoms with small slopes, to the steep ones that in certain points could characterize reliefs, with an average altitude of 820 meters (CEMIG, 2009).

\subsection{Implantation and conduction of the experiment}

Prior to the implementation of the experiment, the area was cleaned by means of mowing or harvesting, according to each treatment. In the planting of the seedlings, pits of $30 \times 30 \times 30 \mathrm{~cm}$ were opened and fertilized with $150 \mathrm{~g}$ of simple superphosphate (P2O5).

The experiment was installed in March 2015, using tree seedlings with approximately six months of age and a mean height of $30 \mathrm{~cm}$. A total of 11 native species were recorded in the region (Platycyamus regnelli Benth., Copaifera langsdorffi Desf., Dalbergia nigra (Vell.) Allemão ex Benth., Enterolobium contortisiliquum (Vell.) Morong, Hymenaea courbaril (L.), Inga sessilis (Vell.) Mart., Melanoxylon brauna Schott, Tapirira guianenses Aubl., Joanesia princeps (Vell.), Anadenanthera colubrina (Vell.) Brenan, and Eugenia uniflora (L.).

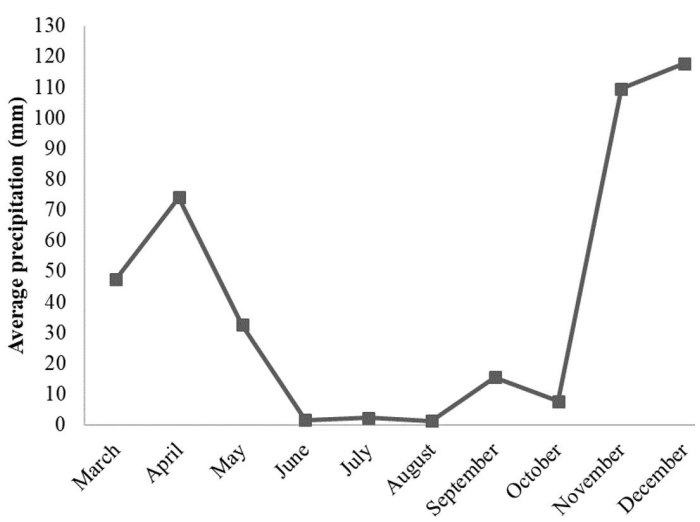

Figure 1. Average precipitation (mm) observed throughout the experiment in Capelinha, Minas Gerais (INMET, 2016).
The seedlings of nine of the eleven species used were produced in the nursery of the State Forestry Institute (IEF - Instituto Estadual de Florestas) of Capelinha, Minas Gerais, while two had their production in the Integrated Center of Propagation of Forest Species of the Federal University of the Valleys of Jequitinhonha and Mucuri (Centro Integrado de Propagação de Espécies Florestais da Universidade Federal dos Vales do Jequitinhonha e Mucuri).

The experiment was installed in a randomized block design, in a factorial arrangement of $2 \times 3 \times 2+2$ (planting $\times$ planting density $\times$ forms of Pteridium aquilinum removal +2 additional treatments), where two models of planting were tested: one made by fast-growing species and another by a mixture of fast and slow growing species, combined with three planting densities (2000 plants/ha, 3000 plants/ha, 4000 plants/ha) and two types of mechanical removal of the bracken: one by means of mowing and another by means of harrowing, in addition to two additional treatments, only with the mechanical removal factor of the bracken, where one was mowed and the other harrowed (Table 1).

Three blocks were installed and, in each of them, 12 plots of $10 \times 10 \mathrm{~m}$ were established. A total of 350 seedlings were planted in each block, distributed in three planting densities (2000 plants/ha, 3000 plants/ha, 4000 plants/ha), according to each treatment. To compose the whole experiment (the sum of the three blocks), 1050 seedlings were planted.

The evaluated variables were seedling survival and bracken cover. Three evaluations were performed 3,6 and 9 months after planting. The survival assessment was based on the counting of live individuals during the three evaluations, in order to obtain the percentage of live seedlings in relation to the number of seedlings planted.

For the evaluation of the bracken cover, central plots of $1 \mathrm{~m}^{2}$ were established in each treatment, and the interpretation was performed using the Braun-Blanquet scale (Braun-Blanquet, 1979).

All data were initially tested for their normality by the Shapiro-Wilk test. Survival data were submitted to analysis of variance and then the Tukey test was performed at $5 \%$ significance. When there was no significance of the data, they were submitted to descriptive analysis. All analyses were performed 
Table 1. Relation of the 14 treatments evaluated in bracken control in the restoration of an Atlantic Forest area in the municipality of Capelinha, Minas Gerais.

\begin{tabular}{|c|c|c|c|}
\hline Treatments & Models of planting & $\begin{array}{l}\text { Planting densities } \\
\left.\text { (plants.ha }{ }^{-1}\right)\end{array}$ & $\begin{array}{c}\text { Mechanical removal of } \\
\text { the bracken }\end{array}$ \\
\hline AT 1 & - & - & Mowing \\
\hline AT 2 & - & - & Harrowing \\
\hline T3 & Fast growing & 2000 & Mowing \\
\hline T4 & Fast growing & 2000 & Harrowing \\
\hline T5 & Fast growing & 3000 & Mowing \\
\hline T6 & Fast growing & 3000 & Harrowing \\
\hline T7 & Fast growing & 4000 & Mowing \\
\hline $\mathrm{T} 8$ & Fast growing & 4000 & Harrowing \\
\hline T9 & Planting fast and slow growing species & 2000 & Mowing \\
\hline T10 & Planting fast and slow growing species & 2000 & Harrowing \\
\hline T11 & Planting fast and slow growing species & 3000 & Mowing \\
\hline T12 & Planting fast and slow growing species & 3000 & Harrowing \\
\hline T13 & Planting fast and slow growing species & 4000 & Mowing \\
\hline T14 & Planting fast and slow growing species & 4000 & Harrowing \\
\hline
\end{tabular}

Legend: Fast growing = Platycyamus regnelli, Enterolobium contortisiliquun, Inga sessilis, Tapirira guianensis, Anadenanthera colubrina. Planting fast and slow growing species = Platycyamus regnelli, Enterolobium contortisiliquun, Inga sessilis, Tapirira guianensis, Anadenanthera colubrina, Copaifera langsdorfi, Dalbergia nigra, Hymenaea courbaril, Melanoxylon braúna, Joanesia princeps, Eugenia uniflora. $\mathrm{T}=$ Treatments. AT $=$ Additional treatments.

in the $\mathrm{R}$ program ( $\mathrm{R}$ Core Team, 2013). In addition, the coverage data were correlated with the survival variable according to Spearman's Correlation, using the BIOESTAT program (Ayres et al., 2007).

\section{RESULTS AND DISCUSSION}

\subsection{Cover of Pteridium aquilinum}

After analyzing the variance of the cover data, it was possible to verify a significant difference $(\mathrm{p}<0.05)$ only for the bracken type removal factor, when considering the general average of the three evaluations, while no significant interactions among the factors were identified. The Spearman correlation was not significant among the analyzed variables $(\mathrm{r}=0.1866, \mathrm{p}=0.6033)$.

The lower coverage with Pteridum aquilinun occurred in the treatments where the harrowing was performed (Figure 2).

A similar result was observed by Cervasio et al. (2009), who tested methods of bracken control in Italy, verifying the efficiency of harrowing since the number of individuals was reduced and the natural regeneration of native species induced. Pteridium aquilinum is a rhizomatous plant (Guerin \& Durigan, 2015). In general, the rhizomes and their rhizophores are deeply buried, allowing the

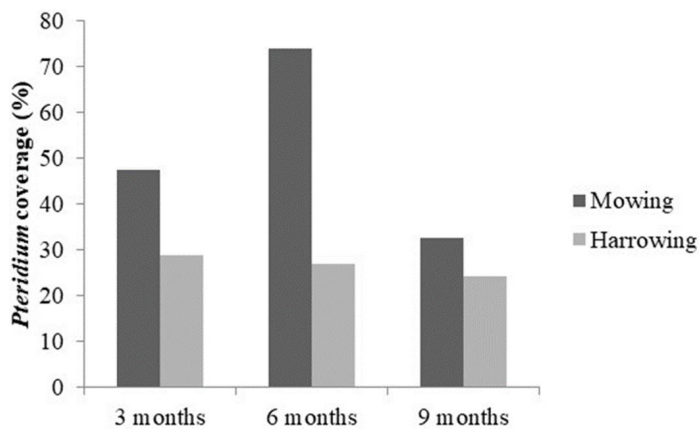

Figure 2. Mean values of bracken cover according to the types of bracken removal 3,6, and 9 months after planting the seedlings for the restoration of an Atlantic Forest area in the municipality of Capelinha, Minas Gerais.

bracken to withstand environment adversities, acting as a storage organ, besides having expansion properties, facilitating the colonization and fixation of the plant in the environment (Atkinson, 1989). Its rhizomatous breeding system allows competition with other species by natural resources, compromising natural regeneration (Marrs et al., 2000). When the harrowing is performed, the soil is revolved, promoting the cutting of the rhizomes, thus affecting the rhizomatous network and consequently the propagation, nutrition and stability of the species (Pakeman \& Marrs, 1992). 
During the month of April, there was an increase in the coverage of Pteridium aquilinum in treatments where the control was performed by mowing. This increase was corroborated with a higher precipitation in the same month (Figure 1). In dry periods, the apical growth of the Pteridium aquilinum is reduced, which contributes to the decrease of the number of its fronds (Gordon et al., 1999). The greater precipitation in the month of April may have contributed to the breakdown of apical bud dormancy, which culminated in the greater coverage of the invader at this time. In addition, in May, the rainfall reduction was very close to the previous month and the coverage was reduced again. During periods of higher drought, the bracken, despite being able to store water in its rhizomes, presented higher mortality rates of its fronds, as a strategy to reduce water loss through evapotranspiration (Roos et al., 2010), which explains the reduction of the cover this month.

Direct control methods, such as cutting, herbicide use and soil shifting, are effective in the short term, but do not guarantee that the bracken will not return to the area initially invaded (Kettenring \& Adams, 2011). In order to obtain more effective and permanent results, it is recommended to use these interventions in conjunction with subsequent treatments, such as planting of seedlings, in order to establish a native vegetation, covering the area in a way that does not allow the return of the bracken (Douterlungne et al., 2013).

\subsection{Survival of seedlings}

The total survival, nine months after planting, was $76.55 \%$, corresponding to 803 seedlings of 1050 planted. According to Knowles \& Parrota (1995), in plantings of seedlings in degraded areas, survival values of over $75 \%$ are considered high. Durigan \& Silveira (1999) consider satisfactory survival values above $60 \%$. In general, the planting presented high survival, confirming that the species used seem to have adapted well to the local conditions, besides not having suffered from the competition caused by the bracken.

It was not possible to observe a significant difference $(p<0.05)$ between treatments. According to the descriptive analysis, maximum survival values were found in treatments T12 (86.66\%) and T14 (82.06\%), harrowed with mixed planting and density of 3000 plants/ha (Table 2).
In the $\mathrm{T} 2, \mathrm{~T} 3, \mathrm{~T} 4, \mathrm{~T} 5, \mathrm{~T} 6$, and $\mathrm{T} 7$ treatments, the simple planting model was applied, where there were only pioneers. The species with the highest mortality were Inga sessilis and Tapirira guianensis. Inga sessilis was present in both models of planting; however, in the simple model, the number of seedlings planted was higher, since the number of species used in this model was lower (five species in the simple planting model vs. eleven species used in the model of mixed planting). This fact increased their mortality, reducing the survival of the treatments. In the case of Tapirira guianensis, the availability of seedlings was low, which prevented the use of the species in both models of planting, and was then only used in the simple planting model. Because its mortality was also high, it contributed in an intense way in the reduction of the survival values of the treatments. Therefore, the highest survival rates found were those of the treatments which included mixed planting (of both fast and slow growing species): T9, T10, T11, T12, T13, and T14.

Among the treatments in which the mixed planting model (of both fast growing and slow growing species) was used, the maximum values were obtained in treatments T12 and T14. This may be related to the efficiency of the sorting in bracken control, which resulted in a smaller competition of this species with the seedlings of the species used in the planting. Pakeman et al. (2002) consider that, when using harrowing as a control method, the rhizomes are damaged by reduction of the cover rate, and the competition potential of the species consequently decreases. In addition, densified planting of seedlings allows greater soil cover and hampers the development of the bracken (Piña-Rodrigues et al., 1997; Nascimento et al., 2012), which is a heliophite species (Durão et al., 1995), requiring, therefore, a greater luminous incidence to develop.

Douterlungne et al. (2010, 2013), studying bracken control by planting a fast growing species called balsa (Ochroma pyramidale) in Mexico, found high rates of development and survival of the species with a significant reduction in Pteridium 18 months after planting, triggering the forest succession, and even corroborating the results of this study.

Individually, survival values varied widely among species. In addition, Hymenaea courbaril (94.44\%) and Copaifera langsdorffi (94.13\%) presented the highest survival rates, while Inga sessilis (30.09\%) and 
Table 2. Survival for 11 tree species used in bracken control in the restoration of an Atlantic Forest area in the municipality of Capelinha, Minas Gerais, nine months after planting.

\begin{tabular}{|c|c|c|c|c|c|c|c|c|c|c|c|c|c|}
\hline Species & T3 & T4 & T5 & T6 & T7 & T8 & T9 & T10 & T11 & T12 & T13 & T14 & $\begin{array}{c}\text { MEAN } \\
(\%)\end{array}$ \\
\hline $\begin{array}{l}\text { Anadenanthera } \\
\text { colubrina }\end{array}$ & 91.66 & 100 & 83.33 & 55.55 & 87.5 & 100 & 100 & 100 & 100 & 88.88 & 100 & 100 & 92.24 \\
\hline $\begin{array}{l}\text { Copaifera } \\
\text { langsdorffii }\end{array}$ & & & & & & & 100 & 100 & 77.77 & 100 & 99.66 & 87.3 & 94.13 \\
\hline Dalbergia nigra & & & & & & & 100 & 83.33 & 100 & 88.88 & 83.33 & 100 & 92.59 \\
\hline $\begin{array}{l}\text { Enterolobium } \\
\text { contortisiliquum }\end{array}$ & 100 & 75 & 77.77 & 94.44 & 91.66 & 100 & 50 & 100 & 55.55 & 100 & 83.33 & 83.3 & 84.25 \\
\hline Eugenia uniflora & & & & & & & 66.66 & 100 & 88.88 & 100 & 90 & 100 & 90.92 \\
\hline $\begin{array}{l}\text { Hymenaea } \\
\text { courbaril }\end{array}$ & & & & & & & 83.33 & 83.33 & 100 & 100 & 100 & 100 & 94.44 \\
\hline Inga sessilis & 8.33 & 33.33 & 33.33 & 38.88 & 37.5 & 29.16 & 16.66 & 50 & 11.11 & 44.44 & 25 & 33.3 & 30.09 \\
\hline Joanesia princeps & & & & & & & 83.33 & 83.33 & 66.66 & 77.77 & 75 & 83.3 & 78.24 \\
\hline $\begin{array}{l}\text { Melanoxylon } \\
\text { braúna }\end{array}$ & & & & & & & 70 & 16.66 & 55.55 & 66.66 & 50 & 41.7 & 50.09 \\
\hline $\begin{array}{l}\text { Platycyamus } \\
\text { regnelli }\end{array}$ & 75 & 91.66 & 83.33 & 77,77 & 91,66 & 91,66 & 83.33 & 66.66 & 88.88 & 100 & 100 & 91.7 & 86.8 \\
\hline $\begin{array}{l}\text { Tapirira } \\
\text { guianenses }\end{array}$ & 66.66 & 50 & 44.44 & 33,33 & 50 & 50 & & & & & & & 49.07 \\
\hline MEAN (\%) & 68.33 & 70 & 64.44 & 59.99 & 71.66 & 74.16 & 75.33 & 78.33 & 74.44 & 86.66 & 80.63 & 82.1 & 76.62 \\
\hline
\end{tabular}

T3 = planting fast growing species, mowing, 2000 plants/ha density; T4 = planting fast growing species, harrowing, 2000 plants/ha density; T5 = planting fast growing species, mowing, 3000 plants/ha density; T6 = planting fast growing species, harrowing, 3000 plants/ha density; T7 = planting fast growing species, mowing, 4000 plants/ha density; T8 = planting fast growing species, harrowing, 4000 plants/ha density; T9 = planting fast and slow growing species, mowing, 2000 plants/ha density; T10 = planting fast and slow growing species, harrowing, density 2000 plants/ha; T11 = planting fast and slow growing species, mowing, density 3000 plants/ha; T12 = planting fast and slow growing species, harrowing, 3000 plants/ha density; T13 = planting fast and slow growing species, mowing, 4000 plants/ha density; T14 = planting fast and slow growing species, harrowing, 4000 plants/ha density.

Tapirira guianenses (49.07\%) presented the lowest values (Table 2).

Hymenaea courbaril and Copaifera langsdorffi have often performed well in restoration projects. Sampaio \& Pinto (2007) found a survival rate of $95 \%$ for Hymenaea courbaril nine months after planting in a Cerrado area. Duboc \& Guerrini (2009) and Sampaio et al. (2008), both in degraded areas of Cerrado, and Nunes et al. (2015) in the transition area between the Cerrado and the Caatinga, found survival rates of $73 \%$, $62 \%$, and $56.34 \%$ for Copaifera langsdorffii 12 months, 24 months, and 36 months after planting, respectively. Due to their high plasticity, Hymenaea courbaril is successful both in full sun and in places with more shade (Mazzei et al., 1999), and Copaifera langsdorffi is considered extremely adaptable to different conditions, occurring in both fertile and well drained areas, and in areas of acid and poor soils. These species can be used in the composition of plantations aiming at the restoration of different environments under different conditions (Oliveira et al., 2015). In addition, both
Hymenaea courbaril and Copaifera langsdorffii are species of occurrence in secondary forests, being classified in the ecological group of shade tolerant or late secondary (Cardoso-Leite et al., 2004). Such an ecological group is characterized by tolerating higher levels of shade in its juvenile state (Budowisk, 1965). Therefore, light competition with bracken was not a limiting factor for the survival of these two species.

The bracken, being a halophyte species, competes directly with the native ones for the availability of light, using the formation of a dense canopy as a main strategy in order to prevent the arrival of light in the other species present (Alday et al., 2013). According to the literature, Inga sessilis and Tapirira guianensis are classified from pioneers to early secondary (Carvalho, 2006; Silva \& Corrêa, 2008; Brandão et al., 2009). The main characteristic of these groups is the high affinity for light and consequently the intolerance to shade, especially in the early stages of development (Budowisk, 1965). Thus, the low survival found for these two species may have been characterized by a 
lower tolerance to the shade caused by the bracken in the competitive environment.

Species, in general, presented high survival rates, indicating that the initial restoration action is satisfactory, and when combined with factors that contribute to the reduction of matocompetição, they generate even better results, thus contributing to the restoration process of the area (Ziller, 2001).

\section{CONCLUSION}

The lower coverage rates of Pteridium aquilinum were obtained in the treatments in which initial control with harrowing was performed.

The maximum survival values were found in the treatments in which the harrowing was done with a mixed planting model and at higher densities.

Although there was still no statistical difference between treatments, the values found so far lead to the belief that more densified plantations of fast growing species allied to the removal of Pteridium aquilinum by harrowing were more effective in the restoration of areas dominated by bracken.

Researches related to the development of restoration techniques combined with methods of controlling invasive plants are of extreme importance for the maintenance and preservation of protected areas.

\section{ACKNOWLEDGEMENTS}

We thank the Universidade Federal dos Vales do Jequitinhonha e Mucuri and the Departamento de Engenharia Florestal, for the support offered. To the Companhia Elétrica de Minas Gerais for the financing of the project and to Capes for the scholarship.

\section{SUBMISSION STATUS}

Received: 14 nov., 2017

Accepted: 26 apr., 2018

\section{CORRESPONDENCE TO}

\section{Thayane Ferreira Carvalho}

Universidade Federal de Lavras - UFLA, Av. Doutor Sylvio Menicucci, 1001, Aquenta Sol, CEP 37200-000, Lavras, MG, Brasil e-mail: thay.f.c@hotmail.com

\section{FINANCIAL SUPPORT}

CAPES, Companhia Energética de Minas Gerais (CEMIG).

\section{REFERENCES}

Alday JG, Cox ES, Pakeman RJ, Harris MPK, Le Duc MG, Marrs RH. Overcoming resistance and resilience of an invaded community is necessary for effective restoration: a multi-site bracken-control study. Journal of Applied Ecology 2013; 50(1): 156-167. http://dx.doi. org/10.1111/1365-2664.12015. PMid:23718004.

Atkinson TP. Seasonal and altitudinal variation in Pteridium aquilinum (L.) Kunh: fornd and stand types. The New Phytologist 1989; 113(3): 359-365. http://dx.doi. org/10.1111/j.1469-8137.1989.tb02414.x.

Ayres M, Ayres M Jr, Ayres DL, Santos AA. BIOESTAT aplicações estatísticas nas áreas das ciências biomédicas. Belém: Ong Mamiraua; 2007.

Baars FJ, Grossi-Sad JH, Fonseca E. Geologia da Folha Capelinha. In: Grossi-Sad JH, Lobato LM, Pedrosa-Soares AC, Soares-Filho BS, editores. Projeto Espinhaço em CDROM (textos, mapas e anexos). Belo Horizonte: COMIG; 1997. p. 1373-1503.

Brandão CFLS, Marangon LC, Ferreira RL, Silva ACBL. Estrutura fitossociológica e classificação sucessional do componente arbóreo em um fragmento de floresta atlântica em Igarassu-Pernambuco. Agrária 2009; 4(1): 55-61. http://dx.doi.org/10.5039/agraria.v4ila9.

Braun-Blanquet J. Fitosociologia. Bases para el estudio de las comunidades vegetales. Madrid: Blume Ediciones; 1979.

Budowisk G. Distribution of tropical American rain forest species in the light of successional processes. Turrialba 1965; 15(1): 40-42.

Cardoso-Leite E, Covre TB, Ometto RG, Cavalcanti DC, Pagani MI. Fitossociologia e caracterização sucessional de um fragmento de mata ciliar, em Rio Claro/SP, como subsídio à recuperação da área. Revista do Instituto Florestal 2004; 16: 31-41.

Carvalho PER. Espécies arbóreas brasileiras. Brasília: Embrapa Informação Tecnológica; Colombo: Embrapa Florestas; 2006.

Cervasio F, Ponzetta MP, Argenti G, Messeri A, Crocetti C, Staglianò N. Effects of different establishment techniques on pasture improvements for wild animals in the italian Apennine Mountains. Grassland Science in Europe 2009; 14: 76-78.

Companhia Elétrica de Minas Gerais - CEMIG. Plano de Manejo da Reserva Particular do Patrimônio Natural Fazenda Fartura. Santo Agostinho: CEMIG; 2009. 225 p. 
Douterlungne D, Levy-Tacher SI, Golicher DJ, Dañobeytia FR. Applying indigenous knowledge to the restoration of degraded tropical Rain forest clearings dominated by bracken bracken. Restoration Ecology 2010; 18(3): 322329. http://dx.doi.org/10.1111/j.1526-100X.2008.00459.x.

Douterlungne D, Thomas E, Levy-Tacher SI. Fast-growing pioneer tree stands as a rapid and effective strategy for bracken elimination in the Neotropics. Journal of Applied Ecology 2013; 50(5): 1257-1265.

Duboc E, Guerrini IA. Desenvolvimento inicial e nutrição da copaíba (Copaifera langsdorffi Desf.) em áreas de cerrado degradado. Planaltina: Embrapa Cerrados; 2009. (Boletim de Pesquisa e Desenvolvimento, no. 245).

Durão JFC, Ferreira ML, Cabral A, Peleteiro MC, Afonso F, Correia J. Aspectos anatomopatológicos e clínicos da hematúria enzoótica dos bovinos. Revista Portuguesa de Ciências Veterinárias 1995; 90: 132-136.

Durigan G, Silveira ER. Recomposição da mata ciliar em domínio de cerrado, Assis, SP. Scientia Forestalis 1999; 56: $135-144$.

Ferreira OV, Silva MM. O clima da bacia do rio Jequitinhonha, em Minas Gerais: subsídios para a gestão de recursos hídricos. Revista Brasileira de Geografia Física 2012; 5(2): 302-319. http://dx.doi.org/10.26848/rbgf.v5i2.232805.

Ghorbani JA, Le Duc MG, Mcallister HA, Pakeman RJ, Marrs RH. Effects of the litter layer of Pteridium aquilinum on seed banks under experimental restoration. Applied Vegetation Science 2006; 9(1): 127-136. http://dx.doi. org/10.1658/1402-2001(2006)9[127:EOTLLO]2.0.CO;2.

Gordon C, Woodin SJ, Mullins CE, Alexander IJ. Effects of environmental change, including drought, on water use by competing Calluna vulgaris (heather) and Pteridium aquilinum (bracken). Functional Ecology 1999; 13(s1): 96106. http://dx.doi.org/10.1046/j.1365-2435.1999.00012.x.

Guerin N, Durigan G. Invasion impact by Pteridium arachnoideum (Kaulf.) Maxon (Dennstaedtiaceae) on a neotropical savanna. Acta Botanica Brasílica 2015; 29(2): 213-222. http://dx.doi.org/10.1590/0102-33062014abb3722.

Instituto Nacional de Metereologia - INMET. Banco de Dados Meteorológicos para Ensino e Pesquisa [online]. 2016 [cited 2016 Feb 12]. Available from: http://www. inmet.gov.br/portal/index.php?r=bdmep/bdmep

Kettenring KM, Adams CR. Lessons learned from invasive plant control experiments: a systematic review and metaanalysis. Journal of Applied Ecology 2011; 48(4): 970-979. http://dx.doi.org/10.1111/j.1365-2664.2011.01979.x.

Knowles OH, Parrota JA. Amazon forest restoration: an innovative system for native species selection based phonological data and field performance indices. Common Wealth Forestry Review 1995; 74(3), 230-243.

Leão TCC, Almeida WR, Dechoum M, Ziller SR. Espécies exóticas invasoras no Nordeste do Brasil: contextualização, manejo e políticas públicas. Recife: Centro de Pesquisas
Ambientais do Nordeste; Instituto Hórus de Desenvolvimento e Conservação Ambiental; 2011.

Marrs RH, Le Duc MG, Mitchell RJ, Goddard D, Paterson S, Pakeman RJ. The ecology of bracken: its role in succession and implications for control. Annals of Botany 2000; 85(2): 3-5. http://dx.doi.org/10.1006/anbo.1999.1054.

Matos DMS, Pivello VR. O impacto das plantas invasoras nos recursos naturais de ambientes terrestres: alguns casos brasileiros. Ciência e Cultura 2009; 61(1): 27-30.

Mazzei LJ, Sousa-Silva JC, Felfili JM, Rezende AV, Franco AC. Crescimento de plântulas de Hymenaea coubaril L. var. stilbocarpa (Hayne) Lee e Lang. em viveiro. Brasília: Jardim Botânico de Brasilia; 1999. (Boletim do Herbário Ezechias Paulo Heringer, vol. 4).

Minas Gerais (Governo do Estado). Instituto Estadual de Florestas. Deliberação $n^{\circ} 1.434$, de $1^{\circ}$ de setembro de 2009. Institui como Reserva Particular do Patrimônio Natural - RPPN a área denominada "Fartura", no município de Capelinha/MG. Diário Oficial do Estado de Minas Gerais, Belo Horizonte, MG (2009).

Nascimento DF, Leles PSS, Oliveira SN No, Moreira RTS, Alonso JM. Crescimento inicial de seis espécies florestais em diferentes espaçamentos. Cerne 2012; 18(1): 159-165. http://dx.doi.org/10.1590/S0104-77602012000100019.

Nunes YRF, Fagundes NCA, Veloso MDDM, Gonzaga APD, Domingues EBS, Souza HA et al. Sobrevivência e crescimento de sete espécies arbóreas nativas em uma área degradada de floresta estacional decidual, norte de minas gerais. Revista Árvore 2015; 39(5): 801-810. http:// dx.doi.org/10.1590/0100-67622015000500003.

Oliveira MC, Passos FB, Ribeiro JF, Aquino FG, Oliveira FF, Sousa SR. Crescimento de espécies nativas em um plantio de recuperação de Cerrado sentido restrito no Distrito Federal, Brasil. Revista Brasileira de Biociências 2015; 13(1): 25-32.

Pakeman RJ, Marrs RH. Vegetation development on moorland after control of Pteridium aquilinum with asulam. Journal of Vegetation Science 1992; 3(5): 707-710. http://dx.doi.org/10.2307/3235839.

Pakeman RJ, Thwaites RH, Le Due MG, Marrs RH. The effects of cutting and herbicide treatment on Pteridium aquilinum encroachment. Applied Vegetation Science 2002; 5(2): 203-212. http://dx.doi.org/10.1111/j.1654109X.2002.tb00550.x.

Piña-Rodrigues FCM, Lopes LR, Marques S. Sistema de plantio adensado para revegetação de áreas degradadas da Mata Atlântica: bases ecológicas e comparações de estudo/benefício com o sistema tradicional. Floresta $e$ Ambiente 1997; 4: 30-41.

$\mathrm{R}$ Core Team. R: a language and environment for statistical computing [online]. Vienna: R Foundation for Statistical Computing; 2013 [cited 2016 Feb 12]. Available from: http://www.R-project.org/ 
Reis A, Bechara FC, Espíndola MB, Vieira NK, Souza LL. Restauração de áreas degradadas: a nucleação como base para incrementar os processos sucessionais. Natureza \& Conservação 2003; 1(1): 28-36.

Rodrigues RR, Brancalion PHS, Isernhagen I. Pacto pela restauração da mata atlântica: referencial dos conceitos e ações de restauração florestal. São Paulo: LERF/ESALQ; Instituto BioAtlântica; 2010.

Roos K, Rödel HG, Beck E. Short- and long-term effects of weed control on pastures infested with Pteridium arachnoideum and an attempt to regenerate abandoned pastures in South Ecuador. Weed Research 2011; 51(2): 165176. http://dx.doi.org/10.1111/j.1365-3180.2010.00833.x.

Roos K, Rollenbeck R, Peters T, Bendix J, Beck E. Growth of Tropical Bracken (Pteridium arachnoideum): response to weather variations and burning. Invasive Plant Science and Management 2010; 3(4): 402-411. http://dx.doi. org/10.1614/IPSM-D-09-00031.1.

Sampaio JC, Felfili JM, Pinto JRR, Fagg CW. Síntese de experiências em recuperação de áreas degradadas com espécies arbóreas nativas do bioma Cerrado. In: Felfili JM, Sampaio JC, Correia CRMA, organizadores. Bases para a recuperação de áreas degradadas na Bacia do São Francisco. Brasília: Universidade de Brasília, Centro de Referência em Conservação da Natureza e Recuperação de Áreas Degradadas, 2008.

Sampaio JC, Pinto JRR. Critérios para avaliação do desempenho de espécies nativas lenhosas em plantios de restauração no Cerrado. Revista Brasileira de Biociências 2007; 5(S1): 270-272.

Sansevero JBB, Prieto PV, Moraes FD, Rodrigues PJFP. Natural regeneration in plantations of native trees in lowland Brazilian Atlantic Forest: community structure, diversity, and dispersal syndromes. Restoration Ecology 2011; 19(3): 379-389. http://dx.doi.org/10.1111/j.1526100X.2009.00556.x.

Sax DF, Kinlan BP, Smith KF. A conceptual framework for comparing species assemblages in native and exotic habitats. Oikos 2005; 108(2): 457-464. http://dx.doi. org/10.1111/j.0030-1299.2005.13402.x.

Silva LDCR, Corrêa RS. Sobrevivência e crescimento de seis espécies arbóreas submetidas a quatro tratamentos em área minerada no cerrado. Revista Árvore 2008; 32(4): 731740. http://dx.doi.org/10.1590/S0100-67622008000400015.

Universidade Federal de Viçosa - UFV. Fundação Centro Tecnológico de Minas Gerais - CETEC. Universidade Federal DE Lavras - UFLA. Fundação Estadual do Meio Ambiente. Mapa de solos do Estado de Minas Gerais. Belo Horizonte: FEAM; 2010.

Vilà M, Espinar JL, Hejda M, Hulme PE, Jarosik V, Maron $\mathrm{JL}$ et al. Ecological impacts of invasive alien plants: a metaanalysis of their effects on species, communities and ecosystems. Ecology Letters 2011; 14(7): 702-708. http://dx.doi.org/10.1111/j.1461-0248.2011.01628.x. PMid:21592274.

Ziller SR. Planta exóticas invasoras: a ameaça da contaminação biológica. Ciência Hoje 2001; 30(178), 77-79. 